\title{
Retroperitoneal Spread of Fournier's Gangrene: A Rare but Fatal Presentation
}

\author{
${ }^{1}$ Apoorv Goel, ${ }^{2}$ Roli Bansal
}

\begin{abstract}
Fournier's gangrene is severe infective necrotizing fasciitis of the external genitalia predominantly in elderly males. It is usually associated with septic shock and multiorgan failure. A 55-yearold male presented with scrotal edema, pain, and redness over lower abdominal wall and both flanks with features of sepsis and ileus. Intraoperative findings were suggestive of extensive necrotizing fasciitis of scrotum spreading to both inguinal region, right lateral parietal wall, and right psoas muscle.
\end{abstract}

Keywords: Fournier's gangrene, Necrotizing fasciitis, Sepsis.

How to cite this article: Goel A, Bansal R. Retroperitoneal Spread of Fournier's Gangrene: A Rare but Fatal Presentation. Panam J Trauma Crit Care Emerg Surg 2016;5(3):166-168.

Source of support: Nil

Conflict of interest: None

\begin{abstract}
O
La gangrena de Fournier es una fascitis infectiva infecciosa necrotizante de los genitales externos predominantemente en varones ancianos. Generalmente se asocia con shock séptico y falla multiorgánica. Un varón de 55 años presentó edema escrotal, dolor y enrojecimiento sobre la pared abdominal inferior y ambos flancos con características de sepsis e íleo. Los hallazgos intraoperatorios sugieren una fascitis necrotizante extensa del escroto que se extiende tanto a la región inguinal como a la pared parietal lateral derecha y al músculo psoas derecho.
\end{abstract}

Palabras claves: La fascitis necrotizante, La gangrena de fournier, Septicemia.

\section{INTRODUCTION}

Fournier's gangrene was first described by Jean Alfred Fournier in 1883 as fulminant necrosis of the scrotum and penis. ${ }^{1,2}$ It is described as necrotizing fasciitis of external genitalia ${ }^{1}$ and is predominantly seen in elderly

${ }^{1}$ Assistant Professor, ${ }^{2}$ Senior Resident

${ }^{1}$ Department of General Surgery, Santosh Medical College and Hospitals, Ghaziabad, Uttar Pradesh, India

${ }^{2}$ Department of Medicine, Division of Nephrology, University College of Medical Sciences and Guru Teg Bahadur Hospital New Delhi, India

Corresponding Author: Apoorv Goel, Assistant Professor Department of General Surgery, Santosh Medical College and Hospitals, Ghaziabad, Uttar Pradesh, India, Phone: +919910093735, e-mail: drapurvgoel@gmail.com males, diabetics, and immunodeficient states. ${ }^{2,3}$ It is a polymicrobial infection caused mainly by Escherichia coli, Klebsiella, Staphylococcus aureus, Streptococcus species, and anaerobes. ${ }^{1,3}$ Fournier's gangrene extensively spreads to surrounding tissue and results frequently in septic shock and multiorgan failure. ${ }^{1}$ Treatment mainly includes broad spectrum antibiotics and surgical debridement of necrotic tissue. ${ }^{4}$ Mortality and morbidity are relatively high. We present a case of a 55-year-old male diagnosed with Fournier's gangrene, septic shock, and paralytic ileus and found to have extensive retroperitoneal spread including both inguinal region, right lateral parietal wall, and right psoas muscle.

\section{CASE REPORT}

A 55-year-old gentleman with no known comorbid conditions presented in surgical emergency with complaints of gradually progressive scrotal swelling since 4 days, redness and pain over lower abdominal wall and both flanks for last 2 days, and diminished urine output with abdominal distension and vomiting since last 24 hours. On examination, he had tachycardia, systolic blood pressure of $90 \mathrm{~mm} \mathrm{Hg}$, temperature of $101^{\circ} \mathrm{F}$, anxious look, dehydration, scrotal wall edema with erythema, and patches of blackish discoloration. Erythema was extending to lower abdominal wall and both lumbar region with localized guarding over that area along with generalized abdominal distension and absent bowel sounds. A diagnosis of Fournier's gangrene with sepsis and paralytic ileus was made, and the patient was planned for urgent debridement and exploration. Noncontrast computed tomography (CT) scan of abdomen revealed soft tissue gas in the scrotum, retroperitoneal cavity, and anterior abdominal wall with dilated small bowel loops. Further investigations showed raised total leukocyte count $(19,500)$, thrombocytopenia (platelets $-85,000)$, deranged renal function tests (urea-73, serum creatinine -2.8 ), and increased prothrombin time (18 against control of 12). Patient underwent debridement and exploratory laparotomy on the same day.

Intraoperative findings revealed massive necrotizing fasciitis involving scrotum and penis with sparing of testicles, extending to both inguinal region, right lateral parietal wall, and right psoas muscle. Dilated 


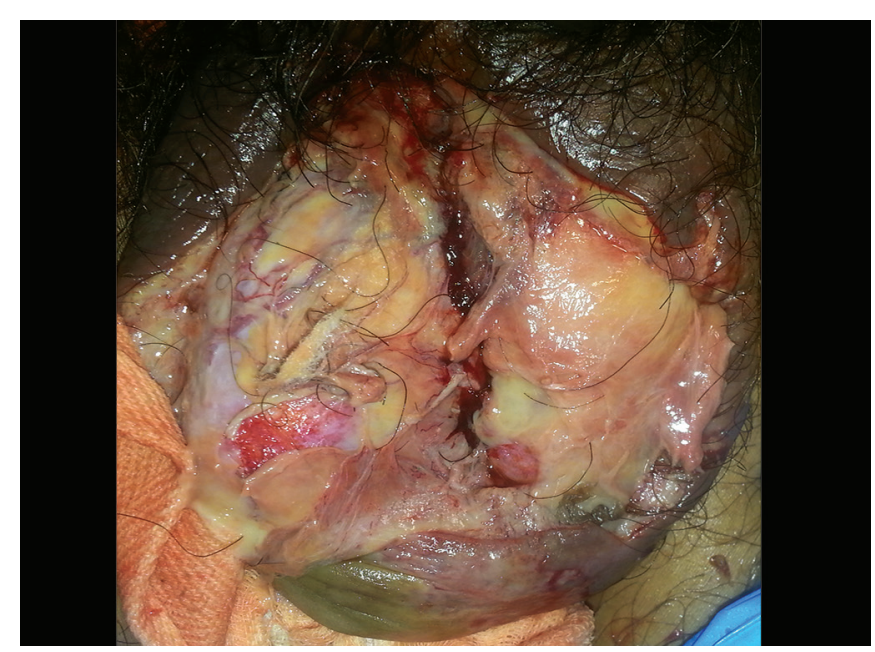

Fig. 1: Case of Fournier's gangrene showing extensive scrotal involvement

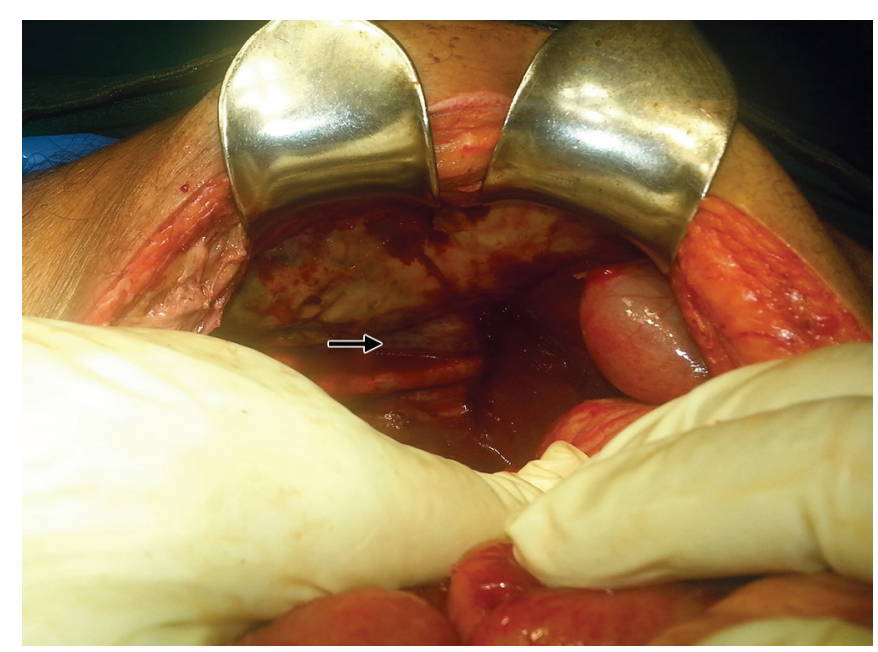

Fig. 2: Retroperitoneal spread and involvement with dilated bowel loops

old age, prolonged steroid use, human immunodeficiency virus, malignancies, and alcohol abuse. The most common source of infection is anorectal $(30-40 \%)^{1}$ followed by urogenital and cutaneous causes. Most common presentation is gangrenous changes of scrotal skin and subcutaneous tissue, sepsis, and multiorgan failure. Fournier's gangrene is associated with high morbidity and mortality $(4-80 \%),{ }^{1,3}$ if not treated promptly. Diagnosis of Fournier's gangrene is usually made by clinical examination, but CT or magnetic resonance imaging can be used to assess the spread and depth of infection.

Several scoring systems had been devised for assessing the severity and prognosis, of which Fournier's gangrene severity index (FGSI) is commonly used. ${ }^{1}$ The FGSI includes various clinical and laboratory parameters, which are used to predict the mortality and disease progression.

Treatment of Fournier's gangrene is early diagnosis and aggressive management in the form of radical surgical debridement, broad spectrum antibiotics, and hemodynamic support with urgent resuscitation. ${ }^{1,4}$ Triple antibiotic therapy consisting of a broad spectrum penicillin or third-generation cephalosporins, an aminoglycoside, and metronidazole or clindamycin is typically instituted empirically. ${ }^{1}$ Other treatment modalities, such as hyperbaric oxygen therapy, closed vacuum drainage, or topical antibiotic application are also known. Once wound is healthy, reconstruction may be planned accordingly.

Fournier's gangrene is known for its fast and extensive spread along the fascial planes to the abdominal wall and even to the thorax. ${ }^{5}$ The infection spreads through the superficial fascial plane (Colles fascia) to deeper fascial planes and involves the penis and scrotum through Buck's and Dartos fascia. ${ }^{1}$ The testicles are usually spared due to different blood supply, but they may be involved in important predisposing factor. ${ }^{3,5}$ Other factors may be 
cases of retroperitoneal spread. ${ }^{1}$ Retroperitoneal spread of Fournier's gangrene is not a common condition; it may arise due to primary source being anorectal or genitourinary. ${ }^{1,5}$ Infection may spread extensively to iliopsoas muscles, lateral parietal wall, colon, or kidneys, but usually spares the large vessels. There are few case reports in the literature discussing the extensive spread of Fournier's gangrene to abdominal wall, peritoneum, thoracic cavity, and even to the retroperitoneal cavity. 5,6 Patients with extensive Fournier's gangrene usually present with multiorgan failure and have high mortality rates. ${ }^{6}$ Such cases should be treated immediately with hemodynamic support, broad spectrum antibiotics, radical surgical debridement, and aggressive wound management. Though this case may not be rare, the message is straight and clear. Early aggressive treatment of Fournier's gangrene is the only way to prevent morbidity and mortality.

\section{REFERENCES}

1. Chennamsetty A, Khourdaji I, Burks F, Killinger KA. Contemporary diagnosis and management of Fournier's gangrene. Ther Adv Urol 2015 Aug;7(4):203-215.

2. Wróblewska M, Kuzaka B, Borkowski T, Kuzaka P, Kawecki D, Radziszewski P. Fournier's gangrene - current concepts. Pol J Microbiol 2014;63(3):267-273.

3. Morua AG, Lopez JA, Garcia JD, Montelongo RM, Guerra LS. Fournier's gangrene: our experience in 5 years, bibliographic review and assessment of the Fournier's gangrene severity index. Arch Esp Urol 2009 Sep;62(7):532-540.

4. Özşaker E, Yavuz M, Altınbaş Y, Şahin Köze B, Nurülke B. The care of a patient with Fournier's gangrene. Ulus Travma Acil Cerrahi Derg 2015 Jan;21(1):71-74.

5. Malik AM, Sheikh S, Pathan R, Khan A, Sheikh U. The spectrum of presentation and management of Fournier's gangrene - an experience of 73 cases. J Pak Med Assoc 2010 Aug;60(8):617-619.

6. Miura K, Kobayashi T, Matsui Y, Fujikawa K, Fukuzawa S, Soeda A, Takeuchi H. Extensive Fournier's gangrene: a case report. Hinyokika Kiyo 2000 Jun;46(6):429-431. 